\title{
The Second Life of Inscriptions in Late Antique and Byzantine Asia Minor: Some Remarks on the Reuse of the Inscribed Material
}

\author{
Georgios PALLIS*
}

When the ancient world began to decline, the lands of the Asia Minor were already littered with a plethora of Greek and Latin inscriptions in stone: laws, letters, decrees, honorific, votive or funerary inscriptions, invocations and all kinds of texts which dated from the Archaic period at the earliest to Late Antiquity at the latest. This material had lost its initial purpose, and its content was considered to be incomprehensible or inaccessible to the people. However, new life was given to it during the Late Antique and Byzantine period, ${ }^{1}$ when it was used as building material. In their new positions, many of these blocks of stones had their inscribed surfaces visible, and this feature poses a series of questions related to the possible perceptions that Byzantine society had for the written word: a) Did the masons and builders understand that those were inscriptions? $b$ ) Did the presence of the text affect the way in which the material was to be treated? c) Can we trace any kind of respect towards these examples of the written word? ${ }^{2}$

The textual sources of the Byzantine period only briefly state anything about such matters and in most cases are related to certain and limited cycles of scholars. According to the 10th c. bishop of Kyzikos Theodore, the inscriptions should be acknowledged as evidence of a bygone prosperity -

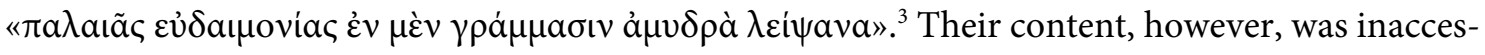
sible for many. Already from the $5^{\text {th }}$ century, an ancient text recovered in the walls of Chalcedon was treated as an oracle and changed the attitude of emperor Valens towards the city. ${ }^{4}$ According

${ }^{*}$ Asst. Prof. Georgios Pallis, Byzantine and Post-Byzantine Archaeology and Art, National and Kapodistrian University of Athens, Department of History and Archaeology, 15784 Athens, Greece (gpallis@ arch.uoa.gr; https://orcid.org/0000-0003-3437-8872).

This article is based on the paper that I delivered in the symposium "Epigraphies in Anatolia. Their histories and their future", held at the Suna and İnan Kıraç Research Center for Mediterranean Civilizations, Antalya, on 24-27 April 2018. I would like to thank the organizers professors Charlotte Roueché and Fatih Onur for their kind invitation to participate in the symposium. I am also thankful to the reviewers of the essay for their precious comments. For the inscriptions cited, I am using the most recent edition of each text.

${ }^{1}$ In terms of chronology, I am following the division used in the recent volume on the Archaeology of Byzantine Anatolia: Early Late Antique Period, $3^{\text {rd }}-$ mid $5^{\text {th }}$ centuries; Early Byzantine period, $5^{\text {th }}-7^{\text {th }}$ centuries; Invasion period, $7^{\text {th }}-9^{\text {th }}$ centuries; Middle Byzantine period, $9^{\text {th }}-11^{\text {th }}$ centuries (Niewöhner 2017, 4 and 6).

${ }^{2}$ The same issues are traceable in other Byzantine provinces as well; in a yet unpublished paper delivered at the XV. Internationaler Kongress für griechische und lateinische Epigraphik (Vienna, 28 August - 1 September 2017) under the title "Ancient Texts in Byzantine Context. Remarks on the Function of Ancient Greek Inscriptions Reused in Byzantine Church Architecture”, I have studied the relevant material from Greece.

${ }^{3}$ Tziatzi-Papagianni 2012, 6, Letter n. A.1, lines 22-23.

${ }^{4}$ Socr.Schol. VIII, 3-9. Coates-Stephens 2002, 280-281. 
to the $8^{\text {th }}$ century Parastaseis syntomoi chronikai, the inscriptions were thought to be a code with prophecies about the future, accessible only to men of extraordinary wisdom. ${ }^{5}$ Even a scholar of the rank of Michael Psellos could not manage explain the meaning of an inscription when he was asked to in the reign of Constantine X Doukas (1059-1067). ${ }^{6}$ On the other hand, several intellectuals searched for inscriptions of literary value: Gregory of Kampsa copied himself epigrams and other texts from stones found in Asia Minor and the Greek mainland in the $9^{\text {th }}$ century. ${ }^{7}$

Outside the literary circles, it is more than obvious that there would have been a complete incapability of even reading the texts. ${ }^{8}$ However, the existence of letters on stones must have been easily understood by every person in Byzantium, as it would have been familiar at least optically from the inscriptions which accompanied the scenes and the holy persons depicted on both portable icons and frescoes.

Conversely, the stones themselves can actually give us some hints about their new life or treatment from their placement or the way in which they were used. However, dealing with the Asia Minor material is a somewhat difficult task. The number of the reused inscriptions is enormous and to overview all cases at once is infeasible. Furthermore, in different kinds of publications, the texts are not always accompanied by the information concerning the way in which each stone was reused, which overlooks much of what is of interest here -a feature that used to be the norm in early publications. Hence, the most secure cases suitable for study are the inscriptions still left in situ or those that were published with a detailed record of their data. In this article, we will limit ourselves only to a brief overview by choosing those cases that are well studied and fully published in order to make observations, which may have a general value.

Reusing older inscriptions is rather an aspect of using spolia in architecture, which as a practice gained much acceptance from the $3^{\text {rd }}$ century A.D. onwards. ${ }^{9}$ What differentiates the blocks of inscriptions from the rest of the reused material is precisely the existence of the written word; they are not simply sculptural architectural members but agents of a verbalized message. The exploitation of inscribed blocks appears in Asia Minor already from the $3^{\text {rd }}$ century when such material was used in the fortifications that were hastily built to protect the cities of Western Asia Minor from the raids of the Goths. A telling example of this is the so-called Gothic wall of Miletus, which was built probably after 263 and was full of spolia. ${ }^{10}$

\footnotetext{
${ }^{5}$ Cameron - Herrin 1984, 146 (65,16-19).

${ }^{6}$ Dagron 1983.

7 PmbZ 22372, 566-567, with further literature. His collection was incorporated into Constantine Kephalas' Anthology (on the sources of Kephalas see Lauxtermann 2007).

${ }^{8}$ On the issue of literacy in medieval Byzantine society see Jeffreys 2008, with further bibliography.

${ }^{9}$ Recent works of general value on the use of spolia in late antiquity and the middle ages: Alchermes 1994; Kinney 1997; Saradi 1997; Ousterhout 1999, 140-145, fig. 103-107; Coates-Stephens 2002; Hansen 2003; Greenhalgh 2008; Brilliant - Kinney 2011; Geymonat 2012; Altekamp et al. 2013; Hansen 2015; Frey 2016; Altekamp et al. 2017; Altuğ 2018; Ng - Swetnam-Burland 2018; Yalman - Jevtić 2018. On the use, especially of inscriptions as spolia, see Cooley 2000; Coates-Stephens 2002; Moralee 2006; Sitz 2019a; Sitz 2019b.
}

${ }^{10}$ Niewöhner 2008, 184-186, Abb. 1-2. 
The reuse of the inscriptions became even more widespread during the Early Byzantine period $\left(5^{\text {th }}-7^{\text {th }}\right.$ centuries) and this continued through the end of Byzantine sovereignty in the region in the 13th century. In this long period, this practice had periods of intensiveness and periods of decline, according to the historical circumstances prevailing or to the relevant demand in architectural practice. The latter can be categorized into three major fields: fortifications, public infrastructure and churches.

\section{Inscriptions reused in fortifications}

As already mentioned, the fortifications were of prime importance in the building activity from the $3^{\text {rd }}$ century onwards. The most common trait of fortifications is the massive reuse of building material from ancient ruined structures; inscriptions were included in this material indistinguishably as we can see them today placed in many different positions. From the very dawn of the Byzantine period this can be exemplified in the city wall of Aphrodisias, which was built by 360 A.D. ${ }^{11}$ The epigraphic material -ca. 450 inscriptions- came from pedestals of monuments that were once used to decorate public spaces, like the theater or the stadium, and from funerary monuments that were at the outskirts of the city. It should be noted here that for a part of the material the inscribed surfaces were systematically hidden inside the masonry.

The building of defensive walls reached its peak during the period of the invasions (7th-9th centuries), when many of the cities faced the danger of a Persian or an Arab raid. In Ephesus, ${ }^{12}$ Pergamum $^{13}$, Patara ${ }^{14}$ and many other inhabited places new walls were built using spolia and among them inscriptions. A remarkable example is that of Sardis, where a fortress was built by the end of the $7^{\text {th }}$ century/early $8^{\text {th }}$ century at the top of the hill of the Acropolis. ${ }^{15}$ Notwithstanding the extensive reuse of older material, in this case, there is a conscious effort to arrange the stones in zones horizontally. As it would be normal, among the spolia there is a great number of inscriptions ${ }^{16}$, the most recent of which has been dated to $539 .{ }^{17}$

In the Middle Byzantine period $\left(9^{\text {th }}-11^{\text {th }}\right.$ centuries), when the cities gradually shrunk and turned into castles, the use of spolia and inscriptions continued with the same frequency. By the middle of the $9^{\text {th }}$ century the emperor Michael III took up a vast restoration program of the fortifications in the most prominent cities of Asia Minor; the best-preserved parts of the fortifications of the $9^{\text {th }}$ century are those of Nicaea and Ankara. The latter presents an especially interesting case as both Greek and Latin inscriptions have been reused (fig. 1), ${ }^{18}$ while new ones were inserted to commemorate the rebuilding of the walls by the emperor. ${ }^{19}$ If we take into consideration that Michael

${ }^{11}$ de Staebler 2008a and 2008b.

${ }^{12}$ Ladstätter 2017, 241.

${ }^{13}$ Oten 2017, 228-229.

${ }^{14}$ Peschlow 2017, 285.

${ }^{15}$ Butler 1969, 21-25, f. 13-15; Foss 1976, 57-59, f. 33-34; Rautman 2017, 234-235, f. 18.3.

${ }^{16}$ Buckler - Robinson 1932, nos 9, 10, 13, 15, 19, 31, 44, 45, 56, 74, 78, 81, 83, 99, 148, 197.

${ }^{17}$ Grégoire 1922, 114-116, n. 324; Foss 1976, 58, 116.

${ }^{18}$ Bosch 1967, 353-355, n. 290-291; French 2003, 86-87 n. 03, 96-97 n. 09; Mitchell - French 2012, 179181 n. 32, 195-197 n. 43.

${ }^{19}$ Grégoire 1927-28, 437-449, n. I-III; French 2003, 196-197, n. 80; Peschlow 2015, 159-162. 
III was aware of the value of the written word as an agent through which his deeds could live in perpetuity, then could the mixed use of ancient and new inscriptions have been intended to symbolize a "dialogue" between the past and the present? Nevertheless, the rather random placement of the majority of the inscribed spolia, in an askew or reversed position, does not enhance such an interpretation.

The precinct wall of the upper city in Amorium, one of the most prominent centers of Asia Minor, had great numbers of inscriptions cut in pieces, reused as a building material. ${ }^{20}$ Among them stand out the inscribed funerary doorstones ${ }^{21}$ and a slab from a Heroon of the Imperial period. ${ }^{22}$ It is clear from the way in which they were treated that they were only meant to be used as raw materials.

\section{Inscriptions reused in public infrastructure}

Apart from the defensive walls, the use of inscribed material extended into the construction of public infrastructure. In the new aqueduct, which was built between 549-565 to secure the water supply to the great basilica of St. John the Theologian in Ephesus, large quantities of spolia were utilized, many of which were inscribed. ${ }^{23}$ Furthermore, the construction of the piers for the duct was facilitated by the shape of many inscribed blocks of stones, which came from the Artemision of Ephesus; some of them are still visible at the surviving parts of the aqueduct in Selçuk. The same can also be observed on a smaller scale in another aqueduct that was built at the end of the $6^{\text {th }} /$ early $7^{\text {th }}$ century at Mylassa in Karia. ${ }^{24}$ The pillars of the arcade were built with ancient material among which were inscriptions too.

\section{Inscriptions reused in church architecture}

The importance of ecclesiastical buildings in Byzantine architecture is very well-known. Historically the churches are buildings of high aspirations, employing raw materials of good quality among which spolia are also included. The recycling of epigraphic material is extensive and has been found in all the cities of Asia Minor, especially during the Early Byzantine period $\left(5^{\text {th }}-7^{\text {th }}\right.$ centuries), at which time numerous basilicas were built. Many of these basilicas occupied central places in the ancient urban fabric, where once many texts of a public character were displayed.

For instance, in Ephesus, both the basilica of Saint Mary (late $4^{\text {th }}$-early $5^{\text {th }}$ century) and the justinianic complex of the church of Saint John the Theologian have employed tens of inscriptions as building material. ${ }^{25}$ The majority of them most probably were not visible as the walls were covered by marble revetments and plaster, while new ones were added at later phases or during restoration works. Built ca. 500, the Temple Church in Aphrodisias includes numerous inscriptions from

\footnotetext{
${ }^{20}$ Harisson et al. 1993, 155-156.

${ }^{21}$ Lightfoot 2017, 35 n. 55, 36-37 n. 59, 38 n. 63, 39 n. 67, 41-42 n. 80.

${ }^{22}$ Lightfoot 2017, 29, n. 23.

${ }^{23}$ Wiplinger 2010, 608.

${ }^{24}$ Ruggieri 2005, 56-57, f. II/1-3.

${ }^{25}$ On the use of spolia in both buildings, see the comments in Karydis 2011, 39-42, fig. 42-47, with references to the numerous inscriptions.
} 
earlier buildings and especially the pagan temple of Aphrodite. ${ }^{26}$ Inscribed material has also been traced in basilicas in Heraclea Pontica ${ }^{27}$, Nakoleia ${ }^{28}$, Hierapolis ${ }^{29}$, Patara ${ }^{30}$ and elsewhere.

After the $7^{\text {th }}$ century, church building activity was reduced impressively for quite a long period. The numbers of epigraphic spolia increased during the new flourishing of ecclesiastical architecture from the $9^{\text {th }}$ century onwards. In the so-called Lower City Church at Amorium, which was rebuilt after 838 , the excavation works brought to light many fragments that would have been embedded in the vault that collapsed. ${ }^{31}$ Still in situ are parts of a Roman inscribed architrave which was immured turned upside down (fig. 2), ${ }^{32}$ as well as the base of the column of Conon the Martyr with its corners only trimmed. ${ }^{33}$ It is noteworthy that on the latter the clearly legible words Christ

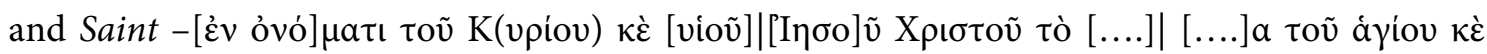

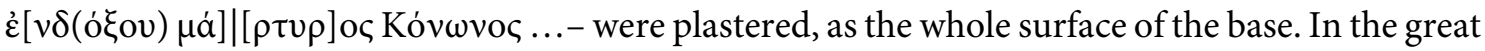
church of Dereağzı in Lycia (ca. 900), four inscriptions were cut in pieces to fill in a cornice while another one was used as a door jamb. ${ }^{34}$ Tens of inscribed stones were reused in the Middle Byzantine refurbishment of the Temple Cathedral at Aphrodisias; ${ }^{35}$ partially plastered inscriptions were incorporated into the $10^{\text {th }}-11^{\text {th }}$ century templon of the same church. ${ }^{36}$

Closely related to the churches are the burial customs, with graves now dug either in their interior or in the surrounding areas. From the numerous burials that were excavated in the Lower City Church of Amorium many examples of reuse of inscribed stones were recorded. ${ }^{37}$ The case of the box-shaped grave 19 from the narthex of the church is of interest here, as an Early Christian slab in second use was placed on its side, forming the inner wall of the west side of the grave, where the head of the deceased was to rest (fig. 3); the slab had a cross and the name of an Etherios carved on its surface. ${ }^{38}$ The choice of the slab for this funerary context most probably was intentional rather than purely practical, even if the shape and the size of the slab fit the occasion; the presence of a cross on it indicates that intentionality.

It should also be noted however that reusing inscribed material was not a practice limited only to the Christian realm. The Jewish synagogue of Sardis shows that the practise was also common in

${ }^{26}$ Sitz 2019a, 147-158, fig. 4-9.

${ }^{27}$ Jonnes 1994, 30-31, n. 50, pl. 7.

${ }^{28}$ Cox - Cameron 1937, 111-113 n. 232-234, 118-119 n. 250, 124 n. 264 and pl. 11.

${ }^{29}$ Ritti 2006, 85-86, f. 32-33.

${ }^{30}$ Peschlow 2017, 284.

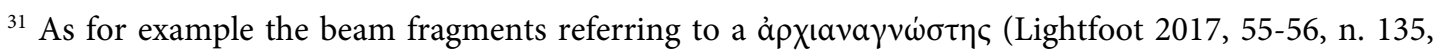
with earlier bibliography).

${ }^{32}$ Lightfoot 2017, 25 n. 8 (with earlier bibliography).

${ }^{33}$ Lightfoot 2017, 55 n. 134 (with earlier bibliography).

${ }^{34}$ Bean 1983, 179-180, n. 2-6, pl. 42,2-44,1.

${ }^{35}$ Hebert 2000, 67-68.

${ }^{36}$ Cormack 1990, 84-87, fig. 2a, 5b, 7b. Hebert 2000, 222-223, pl. 50. Three of them were early Christian inscriptions (Roueché 1989, 9-10 n. 4, 31-32 n. 16, 114 n. 73).

${ }^{37}$ Lightfoot 2017, 58-59 n. 143 and 145.

${ }^{38}$ Lightfoot 2017, 57 n. 139, with earlier bibliography. 
the Jewish communities of Late Antiquity. This luxurious three-aisled complex dated in the second half of the 4th century had inscriptions in the masonry of its pillars. ${ }^{39}$ Among the inscribed findings are also listed a block from the Hellenistic Metroon and a text in an unfamiliar Anatolian alphabet and dialect which is known as the "Synagogue Inscription" ${ }^{40}$ Finally, an observation that is worth mentioning is that no traces of plaster were ever found on the pillars, which means that the inscriptions were visible.

\section{The major phases of reuse}

The cases presented so far from these sites monuments can in fact offer us a basis to create an overall picture of the reuse of the inscribed material in Byzantine Asia Minor. From this picture, we can distinguish three major phases in this practice; the first one can be placed in the $5^{\text {th }}-6^{\text {th }}$ centuries and coincides with the eagerness to spread the new cult; hence building activity was intense due to the erection of the new religious spaces. Furthermore, the great number of the basilicas that were built in the old centers of the ancient urban fabric rearranged the latter giving to it a new form. This activity consequently nullified the inscriptions that were once displayed in the centers of the cities and gave them new uses as they were to be treated as raw materials.

The second phase can be well placed in the $7^{\text {th }}$ century when the invasions of the Persians and the Arabs lead to the accumulation of numerous of spolia as construction material for the erection of new fortifications in towns and cities. In certain cases, the way in which these new defensive walls were built expresses clearly the duress under which they were created. Only sporadically is there a concern in using the material in a more systematic manner.

Finally, the third phase belongs to the Middle Byzantine period where again the church architecture flourishes and epigraphic material is reused frequently. In this last phase, a new category of reused material is now employed: Christian inscriptions from the ruined basilicas and funerary monuments.

\section{The treatment of written word}

The way in which epigraphic material was treated leads us to another array of observations. If we take a better look at the inscriptions we can see that a great percentage of them was left intact; this occurred mainly in the case of bases or pedestals whose cubic shape made it easy for the stone masons to insert them into all kinds of masonry, from walls to aqueducts or other robust structures. The same is also true for the large architrave blocks, which were quite easily used as lintels or transoms. Conversely, some other blocks would have to be cut in pieces in order to fit other more demanding occasions during the erection of a building. This presumably was dictated by practical reasons too; some of the inscribed blocks would have been difficult to move due to their excessive weight or the builders would have to elevate the blocks quite high during building activity.

\footnotetext{
${ }^{39} \mathrm{An}$ inscribed statue base was also found embedded into one of the walls of the building, in an upsidedown position (Mitten - Scorziello 2008, 142, fig. 11-13). On the issue of the date of the synagogue see also Magness 2005, who attributes it to the mid- $6^{\text {th }}$ century.

${ }^{40}$ Mitten - Scorziello 2008, 145-146, fig. 17, 20-21, with further bibliography.
} 
Whichever the case might have been, it should be noted that either intact or cut, the epigraphic material was placed in such a way that the inscribed surface was often left visible. This was not a choice due to some kind of respect for the text itself, as in its new position it could also be placed on its reverse side; rather, being smoother, the inscribed surface was more suitable to the stone masons to elevate it in a vertical wall. It is also not mutually excludable that in cases, e.g. in the walls of Sardis or Ankara where the zones of the marble spolia have irrefutably decorative purposes, an acknowledgement of the aesthetic value of the material determined their placement.

However, visibility of the inscriptions itself was not an obligatory practice; a large number of the material discussed was inserted facing into the masonry and only the cases where a building had been reduced to ruins have allowed us today to locate and study these texts. For instance, at the city wall of Aphrodisias many of the inscriptions were turned to the inside of the masonry; according to Peter de Staebler this seems to have been an intentional choice, because the officials wanted to mitigate the dissatisfaction that might have been caused to the citizens by the destruction of many graves and public monuments for the defensive needs of the city. ${ }^{41}$

Be that as it may, the treatment of the material shows that in many instances it was considered to be ready-made stone fabric to use on the spot. This assertion is enhanced by the examples where the inscriptions were occasionally used in the paving of buildings, as in the Transept basilica at Patara (fig. 4$)^{42}$, or in the Middle Byzantine church at Komana Pontica. ${ }^{43}$ Slightly different is the case of the basilica of the west cemetery at Assos which was restored in the 11th century and was paved with slabs of sarcophagi, some of which, however, were inscribed too. ${ }^{44}$ The existence of letters, which presumably were identified as such, was not an obstacle to give this material a new use, although the congregation would have to step on them. The incorporation of inscribed spolia in pavements of the 4th-5th century central ecclesiastical complex at Gerasa, Jordan, has been interpreted by Moralee as a mean to declare the defeat of the pagan past or even to humiliate the remaining pagan population of the city. ${ }^{45}$ Studying the same practice in the West, in early mediaeval churches of Rome, Coates-Stephens finds only practical motives and "a complete lack of interest in, or awareness of, the inscriptions themselves". ${ }^{46}$

On the other hand, there are also cases where the inscribed surface was chiseled or damaged before it was used. An inscription from the basilica that was built in the cella of Apollo's temple at Didyma had a very deep groove for the securing of a vertically placed slab, which of course destroyed a large part of the text. ${ }^{47}$ In another instance, at Sardis, an inscription was turned into a threshold with notches. ${ }^{48}$ Nevertheless, the letters were still visible on both blocks of stones. Similarly, in the Byzantine shop W8 of Sardis two inscriptions were built in a small basin with the addition of large,

\footnotetext{
${ }^{41}$ de Staebler 2008a, 198.

${ }^{42}$ Adak 1996, 132 n. 6, Taf. 2.

${ }^{43}$ Alten 2015, 79, n. 3.

${ }^{44}$ Böhlendorf-Arslan 2017, 27.

${ }^{45}$ Moralee 2006, 203-205.

${ }^{46}$ Coates-Stephens 2002, 283-287.

${ }^{47}$ Dally et al. 2009, 166-167, K.N. 3.

${ }^{48}$ Buckler - Robinson 1932, n. 54, fig. 44.
} 
well-carved crosses. ${ }^{49}$ In one of the inscriptions, the cross spreads above the whole ancient text which has been turned upside down, while in the other, the text above the upper parts of the cross arms was first erased. ${ }^{50}$ This might have been done in order to make terms the upper part of the sacred symbol clearer.

Removing the letters, although it may have been easy for the stonemasons, was only seldomly practiced from what can be observed. The door lintel of the Temple Church in Aphrodisias (ca. 500 ), originally coming from the pagan temple, was reused after having the references to Aphrodite and her cult chiseled. ${ }^{51}$ The synthronon of the cathedral of Hierapolis $\left(1^{\text {st }}\right.$ half of the $6^{\text {th }}$ century) consisted of inscribed podia whose texts were erased..$^{52}$ The inscription of Philippus Attius in the walls of Side ( $2^{\text {nd }}$ half of $4^{\text {th }}$ century) replaced an older text which was erased, ${ }^{53}$ and this was also the case for the inscription of the comes Phronton (probably $5^{\text {th }}$ century) ${ }^{54}$ In the last two cases, the letters had to be removed because the stonemason wanted to carve new texts within the existing relief frames of tabulae ansatae.

A rare epigraphic palimpsest is found in Sardis: a Roman podium with a Latin inscription honoring Septimius Severus ${ }^{55}$ was reused twice, once in 459 , when on one of its sides was carved a declaration of the guild of the building artisans of the city, ${ }^{56}$ and another in 535, where a speech of a governor of Lydia was carved in the place of the old Latin text. ${ }^{57}$ Interestingly enough, the last inscription did not harm the first line of the older text which started with the words Imp(eratori) Caesa[ri] (fig. 5), a possible indication of respect towards imperial power, which was represented by these widely known titles. ${ }^{58}$ The coexistence of old and new inscriptions was common too. In Heraclea Pontica, a large inscribed architrave mentioning an emperor of the $1^{\text {st }}$ or $2^{\text {nd }}$ A.D. was turned into a sarcophagus in an upside down position, probably in the Middle Byzantine period (fig. 6).$^{59}$ On the narrowest of the three fasciae and above the flipped Roman inscription, the new funerary text commemorating the passing of the servant of God Nikolaos was carved.

There is at last another issue, concerning the perceptions about the magical or supernatural power of word in its written form. Inscriptions on the Byzantine magical amulets were necessary to enact their apotropaic power. ${ }^{60}$ Could the texts on stone be treated as a channel of magical messages or

\footnotetext{
${ }^{49}$ Crawford 1990, 25-26.

${ }^{50}$ Crawford 1990, 29, n. IN59.3-4, fig, 68. See also SEG 43.863 and 46.1525.

${ }^{51}$ Sitz 2019a, 149-151, fig. 4-6.

${ }^{52}$ Ritti 2006, 84.

${ }^{53}$ Nollé 2001, 488-490, n. 167.

${ }^{54}$ Nollé 2001, 467-469, n. 149.

${ }^{55}$ Buckler - Robinson 1932, n. 71.

${ }^{56}$ Buckler - Robinson 1932, n. 18, pl. VII.

${ }^{57}$ Buckler - Robinson 1932, n. 20, pl. VIII, fig. 13.

${ }^{58} \mathrm{Cnfr}$. the reused door lintel over the northern entrance to the nave of Temple Church in Aphrodisias, where a dedication to Augustus Ceasar Pater Patriae was left intact (Sitz 2019a, 148-149).

${ }^{59}$ Hoepfner 1966, 56-57, Abb. 23, Pl. 10e; Jonnes 1994, 33-34 n.58a-b.

${ }^{60}$ Foskolou 2014.
} 
even of evil power, given their pagan origins? The existence of fear of this kind towards inscriptions may explain the insertion of crosses into ancient texts, as for example the cross with the letters $\mathrm{A}$ and $\Omega$ into an inscription in Aphrodisias. ${ }^{61}$ Although such motives are not easily traceable, this case should not be excluded.

\section{Conclusion}

The scholarly research has the tendency to identify in the use of spolia in Byzantium intentions with symbolic motives, such as the victory over the pagan past ${ }^{62}$ the reflection of historical awareness ${ }^{63}$ or the declaration of a local identity ${ }^{64}$ For inscribed spolia material, however, which have not attracted as much the interest of the researchers as the architectural ones, other interpretations proposed include attitudes towards the past or memory, and in specific instances even motivations such as the declaration of "Greekness" in environments where new populations of a different origin were settled, such as the Slavs in the south of Greece. ${ }^{65}$

In the material from Asia Minor, to the degree that it has been examined so far, it seems that practical reasons prevailed. This can be observed in the defensive walls, starting from the case of Aphrodisias with the great number of askew, reversed and hidden texts. A parallel case comes from insular Greece: on the island of Aegina there is the so-called "Inscriptions Wall" of Late Antiquity, which was built with numerous ancient inscriptions both visible on its surface or hidden in its masonry. ${ }^{66}$ As Jon Frey has suggested, the stones were used as raw material, meaning that they were to be placed in the most logical and practical way into the wall. The same practicality must have dominated the ecclesiastical architecture as well, where the masons placed many of the inscriptions reversed or on the inside of a wall. ${ }^{67}$ Additionally, those that were left facing out of the wall were also covered by marble revetments, mural paintings or plasters.

Clearly, the Christian masons worked in a purely technical manner and seem to have ignored the content of the inscribed blocks of stones. Did they employ a different treatment in the case of Christian inscriptions? It seems not, with the exceptions of those instances were a cross was carved on them. The pedestal of Conon at Amorium, with the words Christ and Saint plastered, is quite revealing.

Concluding from the above overview of the epigraphic material from Asia Minor, it can be stated that the way these stones were treated depended mainly on practical factors. The Byzantine world continued to use the written word on a monumental scale, but with a new meaning and purpose than previously. Inscriptions were now used to secure the orthodox doctrine through the numerous names, quotations and epigrams displayed in the Christian church, to teach and guide the faithful, to submit their prayers to God, to commemorate acts of patronage and personal devotion,

\footnotetext{
${ }^{61}$ Sitz 2019a, 142-143, fig. 2.

${ }^{62}$ Cormack 1990, 84-88.

${ }^{63}$ Ousterhout 1999, 145.

${ }^{64}$ Sitz 2019a, 160-161.

${ }^{65}$ Papalexandrou 2003, 72-73.

${ }^{66}$ Frey 2016, 45-84, fig. 3.1-3.20.

${ }^{67}$ Karydis comes to the same conclusion, of basically utilitarian motives, discussing the building materials of Early Byzantine vaults in west Asia Minor (Karydis 2011, 42).
} 
as well as to commemorate the deceased members of church and lay elites. The still present ancient texts were more or less incomprehensible for members of late antique and medieval society, illiterate and literate together. Thus, both the ancient and early Christian texts became raw building materials until the modern era, when awakening of interest in antiquity lead to the systematic recording and study of these stones.

\section{Bibliography}

Adak 1996

Alchermes 1994

Altekamp et al. 2013

Altekamp et al. 2017

Alten 2015

Altuğ 2018

Bean 1983

Bosch 1967

Böhlendorf-Arslan 2017

Brilliant - Kinney 2011

Buckler - Robinson 1932

Butler 1969

M. Adak, Claudia Anassa. Eine Wohltäterin aus Patara, Epigraphica Anatolica 27, 1996, 127-142.

J. Alchermes, Spolia in Roman Cities of the Late Empire: Legislative Rationales and Architectural Reuse, Dumbarton Oaks Papers 48, 1994, 167-178.

St. Altekamp - C. Marcks-Jacobs - P. Seiler (eds.), Perspektiven der Spolienforschung 1. Spoliierung und Transposition, Topoi, Berlin Studies of the Ancient World 15, Berlin-Boston 2013.

St. Altekamp - C. Marcks-Jacobs - P. Seiler (eds.), Perspektiven der Spolienforschung 2. Zentren und Konjunkturen der Spoliierung, Topoi, Berlin Studies of the Ancient World 40, Berlin 2017.

E. Alten, Komana'dan Yeni Yazttlar, in: D. B. Erciyas - M. N. Tatbul (eds.), Komana'da Ortaçağ Yerleşimi/The Medieval Settlement at Komana, İstanbul 2015, 75-82.

K. Altuğ, Reconsidering the Use of Spolia in Byzantine Constantinople, in: S. Pedone - A. Paribeni (eds.), «Di Bisanzio dirai ciò che è passato, ciò che passa e che sarà». Scritti in onore di Alessandra Guiglia, v. I, Roma 2018, 3-16.

G. E. Bean, The roman Inscriptions, in: J. Morganstern (ed.), The Byzantine Church at Dereağzı and its decoration, IstMitt Beiheft 29, Tübingen 1983, 178-181, pl. 42,1-44,4.

E. Bosch, Quellen zur Geschichte der Stadt Ankara in Altertum, Ankara 1967, 353-355, n. 290-291.

B. Böhlendorf-Arslan, Nothing to Remember? Redesigning the Ancient City of Assos in the Byzantine Era, in: E. Mortensen B. Poulsen (eds.), Cityscapes and Monuments of Western Asia Minor, Oxbow 2017, 21-28.

R. Brilliant - D. Kinney (eds.), Reuse Value. Spolia and Appropriation in Art and Architecture from Constantine to Sherrie Levine, Farnham-Burlinghton 2011.

W. H. Buckler - D. M. Robinson, Sardis VII, Greek and Latin Inscriptions, Part I, Leyden 1932.

H. C. Butler, Sardis I. The Excavations, p. I, 1910-1914, Amsterdam 1969. 
Cameron - Herrin 1984

Coates-Stephens 2002

Cooley 2000

Cormack 1990

Cox - Cameron 1937

Crawford 1990

Dagron 1983

Dally et al. 2009

de Staebler 2008a

de Staebler 2008b

Foskolou 2014

Foss 1976

French 2003
A. Cameron - J. Herrin (eds.), Constantinople in the early eighth century. The "Parastaseis syntomoi chronikai", Leiden 1984.

R. Coates-Stephens, Epigraphy as spolia - the reuse of inscriptions in early medieval buildings, PBSR LXX, 2002, 275-296.

A. Cooley, The Life-cycle of Inscriptions, in: A. Cooley (ed.), The Afterlife of Inscriptions. Reusing, Rediscovering, Reinventing and Revitalizing Ancient Inscriptions, London 2000, 1-5.

R. Cormack, The Temple as the Cathedral, in: Ch. Roueché K. T. Erim (eds.), Aphrodisias papers. Recent work on architecture and sculpture, including the papers given at the Second International Aphrodisias colloquium held at King's College, London, on 14 November 1987, JRA Suppl. 1, Ann Arbor 1990, 75-88.

C. W. M. Cox - A. Cameron, Monuments from Dorylaeum and Nacolea (Monumenta Asiae Minoris Antiqua V), Manchester 1937.

J. St. Crawford, The Byzantine Shops at Sardis, Archaeological Exploration of Sardis Monograph 9, Massachusetts 1990.

G. Dagron, Psellos épigraphiste, in: C. Mango - O. Pritsak (eds.), Okeanos. Essays presented to Ihor Ševčenko on his Sixtieth Birthday by his Colleagues and Students, Massachusetts 1983, 117-124.

O. Dally - M. Maischberger - P. Schneider - A. Scholl (eds.), ZeitRäume. Milet in Kaiserzeit und Spätantike, Ausstellungskatalog Berlin 2009, Regensburg 2009.

P. D. de Staebler, Şehir Surlarında Kullanılan Işlemeli Devşirme Mermerler/Re-use of Carved Marble in the City Wall, in: R. R. R. Smith - J. L. Lenaghan (eds.), Aphodisias'tan Roma Portreleri/Roman Portraits from Aphrodisias, Istanbul 2008, 185-199.

P. D. de Staebler, The City Wall and the making of a late-antique provincial capital, in: Chr. Ratté - R. R. R. Smith (eds.), Aphodisias Papers 4. New Research on the City and the Monuments (JRA Suppl 70), Portsmouth 2008, 285-318.

V. A. Foskolou, The Magic of the Written Word: The Evidence of Inscriptions on Byzantine Magical Amulets, Deltion tes Christianikes Archaiologikes Etaireias 35, 2014, 329-348.

Cl. Foss, Byzantine and Turkish Sardis, Cambridge-Massachusetts-London 1976.

D. French, Roman, Late Roman and Byzantine Inscriptions of Ankara. A Selection, Ankara 2003. 
Frey 2016

Geymonat 2012

Greenhalgh 2008

Grégoire 1922

Grégoire 1927-28

Hansen 2003

Hansen 2015

Harisson et al. 1993

Hebert 2000

Hoepfner 1966

Ivison 2010

Jeffreys 2008

Jonnes 1994

Karydis 2011

Kinney 1997

Ladstätter 2017
J. M. Frey, Spolia in Fortifications and the Common Builder in Late Antiquity, Leiden-Boston 2016.

L. V. Geymonat, The Syntax of Spolia in Byzantine Thessaloniki, in: M. J. Johnson - R. Ousterhout - A. Papalexandrou (eds.), Approaches to Byzantine Architecture and its Decoration, Farnham 2012, 47-65.

C. M. B. Greenhalgh, Marble Past, Monumental Present. Building with Antiquities in the Mediaeval Mediterranean, Leiden-Boston 2008.

H. Grégoire, Recueil des inscriptions grecques-chrétiennes d'Asie Mineure, Paris 1922.

H. Grégoire, Inscriptions historiques byzantines, Byzantion 4, 1927-28, 437-468.

M. F. Hansen, The eloquence of appropriation. Prolegomena to an understanding of spolia in early Christian Rome (Analecta Romana Instituti Danici 33), Rome 2003.

M. F. Hansen, The Spolia Churches of Rome. Recycling Antiquity in the Middle Ages, Aarhus 2015.

R. M. Harisson - N. Christie et al., Excavations at Amorium: 1992 Interim Report, AnSt 43, 1993, 147-162.

L. Hebert, The Temple-Church at Aphrodisias, PhD Dissertation, Institute of Fine Arts, New York University, New York 2000.

W. Hoepfner, Herakleia Pontike - Ereğli. Eine baugeschichtliche Untersuchung, Wien 1966.

E. I. Ivison, Kirche und Religiöses Lebens in Byzantinischen Amorium, in: F. Daim - J. Drauschke (eds.), Byzanz - das Römerreich im Mittelalter, T. 2,1, Schauplätze, Mainz 2010, 309343.

M. Jeffreys, Literacy, in: E. Jeffreys - J. Haldon - R. Cormack (eds.), The Oxford Handbook of Byzantine Studies, New York 2008, 796-802.

L. Jonnes, The Inscriptions of Heraclea Pontica (Inschriften griechischer Städte aus Kleinasien 47), Bonn 1994.

N. D. Karydis, Early Byzantine Vaulted Construction in Churches of the Western Coastal Plains and River Valleys of Asia Minor, Oxford 2011.

D. Kinney, Spolia. Damnatio and renovation Memoriae, Memoirs of the American Academy in Rome 42, 1997, 117-148.

S. Ladstätter, Ephesus, in: Ph. Niewöhner (ed.), The Archaeology of Byzantine Anatolia. From the End of Late Antiquity until the Coming of the Turks, New York 2017, 238-248. 
Lauxtermann 2007

Lightfoot 2010

Lightfoot 2017

Magness 2005

Mitchell - French 2012

Mitten - Scorziello 2008

Moralee 2006

$\mathrm{Ng}$ - Swetnam-Burland 2018

Niewöhner 2008

Niewöhner 2017

Nollé 2001

Oten 2017

Ousterhout 1999
M. Lauxtermann, The Anthology of Cephalas, in: M. Hinterberger - E. Schiffer (eds.), Byzantinische Sprachkunst. Studien zur byzantinischen Literatur gewidmet Wolfram Hörander zum 65. Geburtstag (Byzantinisches Archiv 20), Berlin-New York 2007, 194-208.

Chr. S. Lightfoot, Die byzantinische Stadt Amorium. Grabungsergebnisse der Jahre 1988 bis 2008, in: F. Daim - J. Drauschke (eds.), Byzanz - das Römerreich im Mittelalter, T. 2,1, Schauplätze, Mainz 2010, 293-307.

Chr. S. Lightfoot, Amorium Reports 5: A Catalogue of Roman and Byzantine Stone Inscriptions from Amorium and its Territory. Together with Graffiti, Stamps and Miscellanea, Istanbul 2017.

J. Magness, The Date of the Sardis Synagogue in Light of the Numismatic Evidence, AJA 109.3, 2005, 443-475.

St. Mitchell - D. French (eds.), The Greek and Latin Inscriptions of Ankara (Ankyra) I. From Augustus to the End of the Third Century AD, München 2012.

D. G. Mitten - A. Fr. Scorziello, Reappropriating Antiquity. Some Spolia from the Synagogue at Sardis, in: N. D. Cahill (ed.), Love for Lydia. A Sardis Anniversary Volume Presented to Crawford H. Greenewalt, Jr., Cambridge- MassachussetsLondon 2008, 135-146.

J. Moralee, The Stones of St. Theodore: Disfiguring the Pagan Past in Christian Gerasa, Journal of Early Christian Studies 14, 2006, 183-215.

D. Y. Ng - M. Swetnam-Burland (eds.), Reuse and Renovation in Roman Material Culture: Functions, Aesthetics, Interpretations, Cambridge 2018.

Ph. Niewöhner, Sind die Mauern die Stadt? Vorbericht über die siedlungsgeschichtlichen Ergebnisse neuer Grabungen im spätantiken und byzantinischen Milet, AA 2008.1, 255-263.

Ph. Niewöhner, Introduction, in: Ph. Niewöhner (ed.), The Archaeology of Byzantine Anatolia. From the End of Late Antiquity until the Coming of the Turks, New York 2017, 1-6.

J. Nollé, Side im Altertum: Geschichte und Zeugnisse, B. 2 (Inschriften Griechischer Städte aus Kleinasien 44), Bonn 2001.

Th. Oten, Pergamon, in: Ph. Niewöhner (ed.), The Archaeology of Byzantine Anatolia. From the End of Late Antiquity until the Coming of the Turks, New York 2017, 226-230.

R. Ousterhout, Masterbuilders of Byzantium, Princeton 1999. 
Papalexandrou 2003

Peschlow 2015

Peschlow 2017

Rautman 2017

Ritti 2006

Roueché 1989

Ruggieri 2005

Saradi 1997

Sitz 2019a

Sitz 2019b

Tziatzi-Papagianni 2012

Wiplinger 2010

Yalman - Jevtić 2018
A. Papalexandrou, Memory Tattered and Torn: Spolia in the Heartland of Byzantine Hellenism, in: R. M. Van Dyke - S. E. Alcock, Archaeologies of Memory, Oxford 2003, 56-80.

U. Peschlow, Ankara. Die bauarchäologischen Hinterlassenschaften aus römischer und byzantinischer Zeit, Wien 2015.

U. Peschlow, Patara, in: Ph. Niewöhner (ed.), The Archaeology of Byzantine Anatolia. From the End of Late Antiquity until the Coming of the Turks, New York 2017, 280-290.

M. Rautman, Sardis, in: Ph. Niewöhner (ed.), The Archaeology of Byzantine Anatolia. From the End of Late Antiquity until the Coming of the Turks, New York 2017, 231-237.

T. Ritti, An Epigraphic Guide to Hierapolis (Pamukkkale), Istanbul 2006.

Ch. Roueché, Aphrodisias in Late Antiquity. The Late Roman and Byzantine Inscriptions, including texts from the excavations at Aphrodisias conducted by Kenan T. Erim, London 1989.

V. Ruggieri, La Caria Bizantina: topografia, archeologia ed arte (Mylasa, Stratokikeia, Bargylia, Myndus, Halicarnassus), Catanzaro 2005.

H. Saradi, The Use of Ancient Spolia in Byzantine Monuments: The Archaeological and Literary Evidence, International Journal of the Classical Tradition 3, 1997, 395-423.

A. M. Sitz, Hiding in Plain Sight: Epigraphic Reuse in the Temple-Church at Aphrodisias, Journal of Late Antiquity 12.1, 2019, 136-168.

A. M. Sitz, Beyond Spolia: A New Approach to Old Inscriptions in Late Antique Anatolia, AJA 123.4, 2019, forthcoming.

M. Tziatzi-Papagianni (ed.), Theodori Metropolitae Cyzici Epistulae (CFHB 48), Berlin-Boston 2012.

G. Wiplinger, Die Wasserversorgung von Ephesos in byzantinischer Zeit, in: F. Daim - J. Drauschke (eds.), Byzanz - das Römerreich im Mittelalter, Teil 2,2, Schauplätze (Monographien des Römisch-Germanischen Zentralmuseums), Mainz 2010, 593-613.

S. Yalman - I. Jevtić (eds.), Spolia Reincarnated: Afterlives of Objects, Materials, and Spaces in Anatolia from Antiquity to the Ottoman Era/Devşirme Malzemenin (Spolia) Yeniden Doğuşu. Antikçağ' dan Osmanlı'ya Anadolu'da Objelerin, Materyallerin ve Mekânların Sonraki Yaşamları, İstanbul 2018. 


\section{Bizans Dönemi Anadolu'sunda Yazıtların İkinci Hayatı: Yazılı Materyallerin Yeniden Kullanımına İlişkin Görüşler \\ Öz}

Klasik, Roma ve Geç Antik Dönem, Anadolu topraklarına çeşitli içerik ve amaçlar barındıran, taşlar üzerine yazılı binlerce Yunanca ve Latince yazıt miras bırakmıştır. Antik dünyanın çöküşü ve Ortaçağ’a geçiş ile birlikte, bu materyaller kamusal ya da şahsi metinleri taşımaları bakımından önemlerini kaybetmişler ve onlara bakanlar için anlaşılmaz hale gelmişlerdir. Bu süre içerisinde, epigrafi farklı bir yönelim izlemiş ve Hıristiyanlık ile Doğu Roma İmparatorluğu'na ait kurumların hizmetinde yeni değerler kazanmıştır.

Tahkimatlar, kamu altyapısı ve kiliseler bu uzun dönem boyunca bölgedeki inşa faaliyetinde öne çıkmışlardır. Erken dönem materyalleri ile dolu olan antik kent ve alanlarının ilk olarak meydana gelmesinin ardından mimari üretim geniş ölçüde pek çok çeşitte ve pek çok döneme ait devşirme malzeme kullanmıştır. Bu devşirmeler çeşitli yapılar içerisine -hiç bozulmamış ya da yeniden işlenmiş şekilde- konmuş pek çok yazıtı içermektedir. Ankara'nın duvarları, Ephesos kentinin kiliseleri ve diğer anıtlar, sonradan Selçuklu ve Osmanlı Türkleri tarafından da kullanılan bu uygulamayı temsil etmektedirler.

Anadolu'nun Bizans Dönemi anıtlarındaki yazılı devşirme malzemelerin varlığı, bir şekilde değişik formda hâlâ aynı dili konuşan fakat farklı bir kültürü paylaşan bir toplumda yazılı kelimelere karşı gösterilen tutuma dair pek çok sorun ortaya çıkarmaktadır. Bu makale, Anadolu'dan seçilen yeniden kullanılmış epigrafik malzemeler ışığında yazıtların çoğunlukla pratik amaçlarla kullanıldığını iddia etmektedir. Okuma yazma bilen ya da bilmeyen Bizanslılar tarafından neredeyse anlaşılmaz olan yazılı taşlar, savunma yapılarında, sivil binalarda ve kiliselerde yeniden kullanılmak üzere ham inşa malzemesine dönüşmüşlerdir.

Anahtar Sözcükler: Yazıtlar, devşirme malzeme, yeniden kullanım, Asia Minor, Anadolu, Bizans Dönemi.

\section{The Second Life of Inscriptions in Late Antique and Byzantine Asia Minor: Some Remarks on the Reuse of the Inscribed Material}

\section{Abstract}

Classical, Roman and Late antiquity inherited in the land of Asia Minor thousands of older Greek and Latin inscriptions on stone, of various content and purposes. With the collapse of the ancient world and the transition to the medieval period, this material lost its significance as conveyor of public and private texts and became incomprehensible to the viewers. In the meantime, contemporary epigraphy followed a different orientation and acquired new values, in the service of Christianity and the Eastern Roman imperial institutions.

Fortifications, public infrastructure and churches predominate in the building activity in the region during this long period. Taking place primarily at ancient cities and sites full of earlier material, architectural production extensively reused spolia of various kinds and periods. These spolia included many inscriptions, which were embedded -intact or reworked- in various structures. The walls of Ankara, the churches of Ephesus and other monuments are representative of this practice, which was later exercised by the Seljuks and the Ottoman Turks too.

The presence of inscribed spolia in Byzantine monuments of Asia Minor raises several questions about the attitude towards the written word in a society which was still using the same language, 
in a somehow changed form, but was sharing a different culture. Based on selected cases of reused epigraphic material from the Asia Minor, this article argues that inscriptions were treated mainly in practical terms. Being more or less incomprehensible by illiterate and literate Byzantines, inscribed stones became raw building materials available to be recycled in fortifications, secular buildings and churches.

Keywords: Inscriptions, spolia, reuse, Asia Minor, Byzantine era.

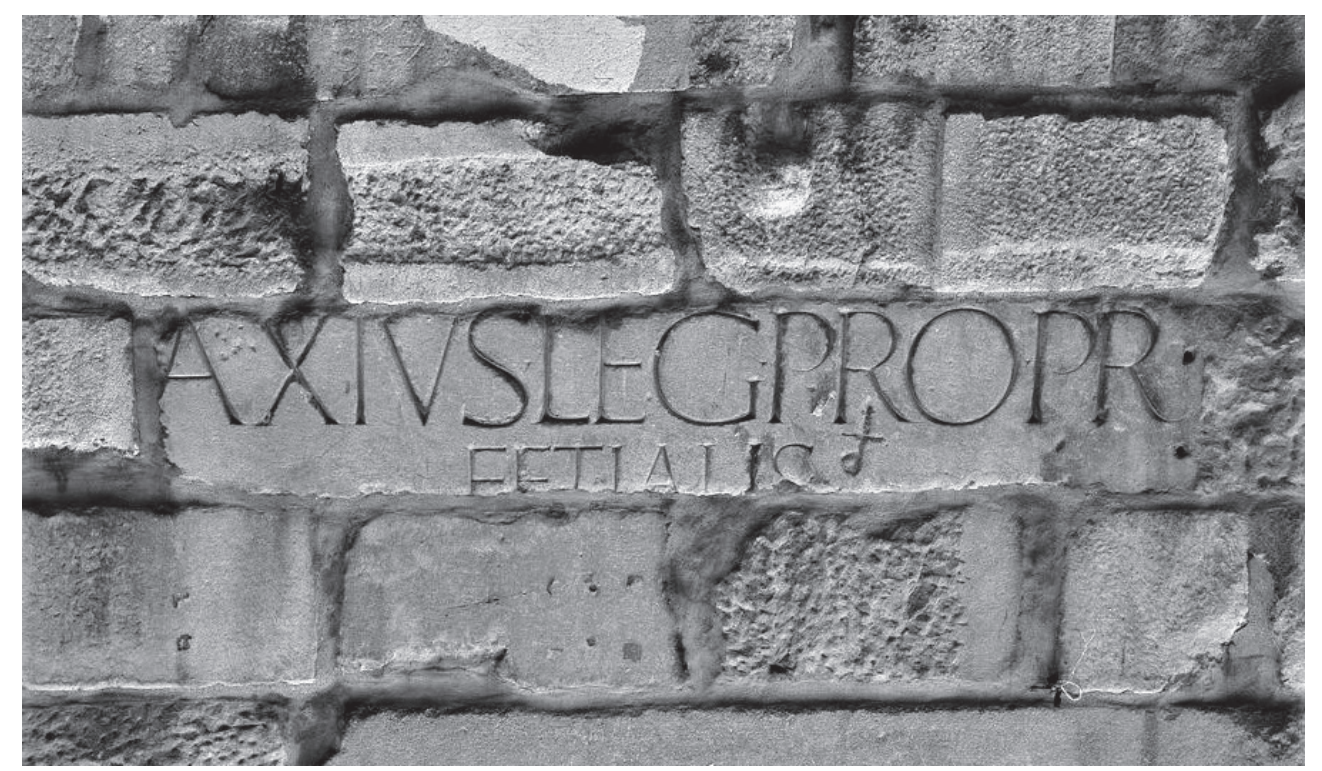

Fig. 1) Ankara, Latin inscription reused in the walls (Mitchell - French 2012, n. 32).

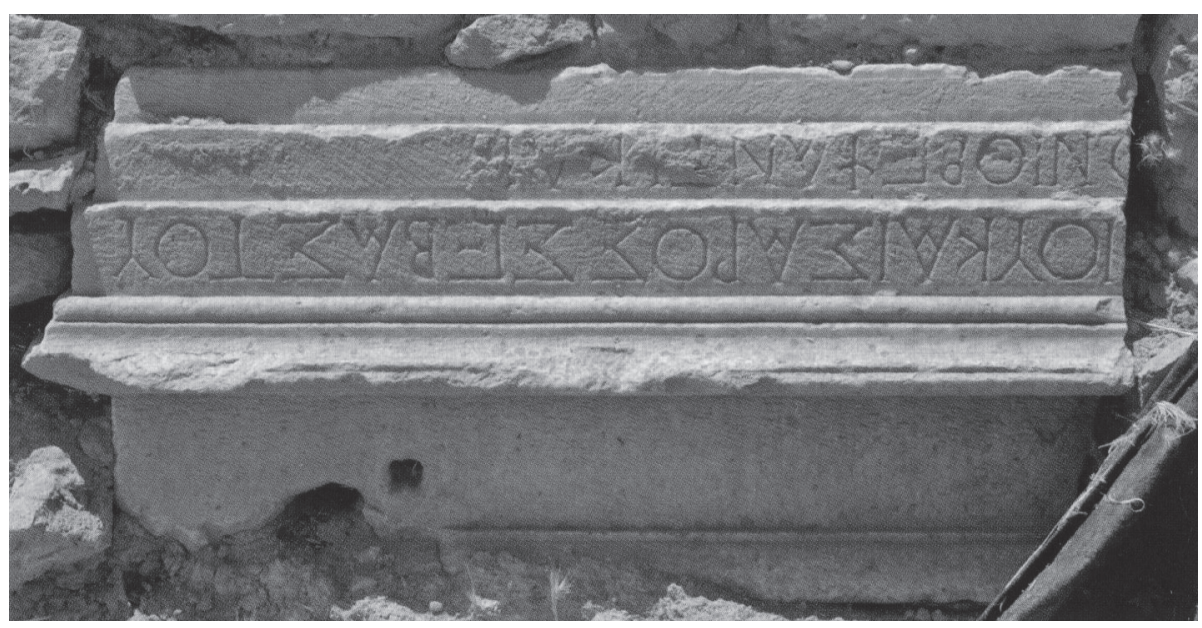

Fig. 2) Amorium, roman architrave embedded in Lower City Church masonry (Lightfoot 2010, Abb. 13). 


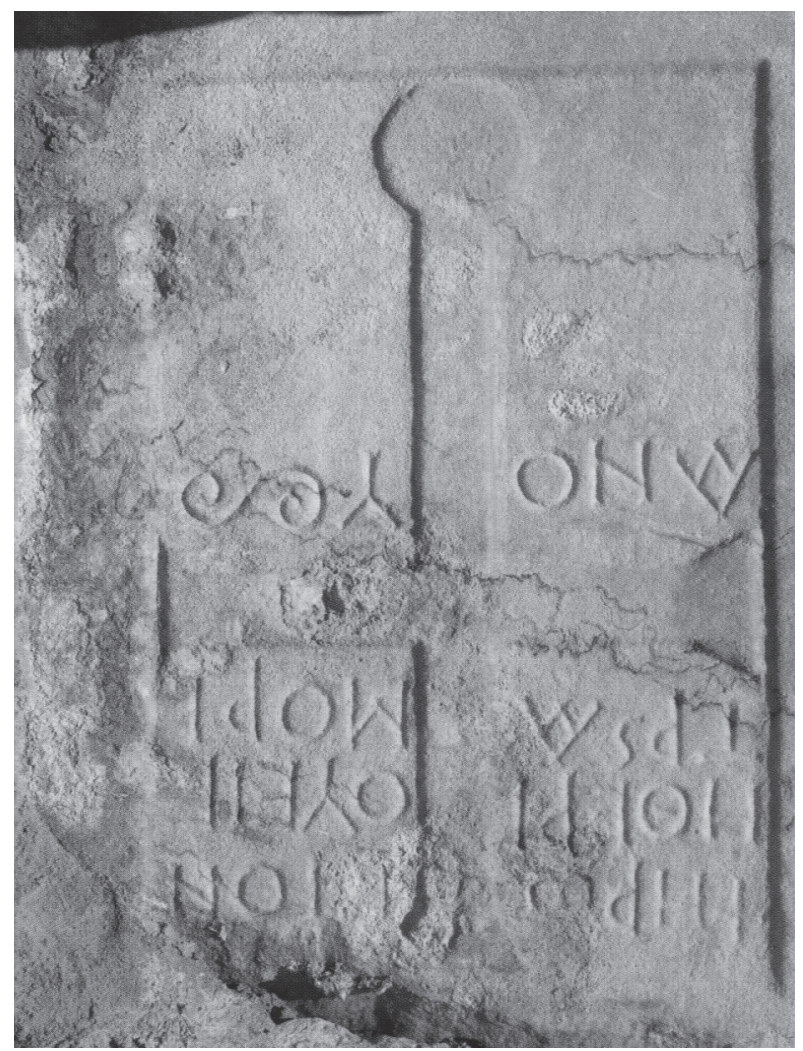

Fig. 3) Amorium, Lower City Church, early Christian slab in grave 19 (Ivison 2010, Abb. 13).

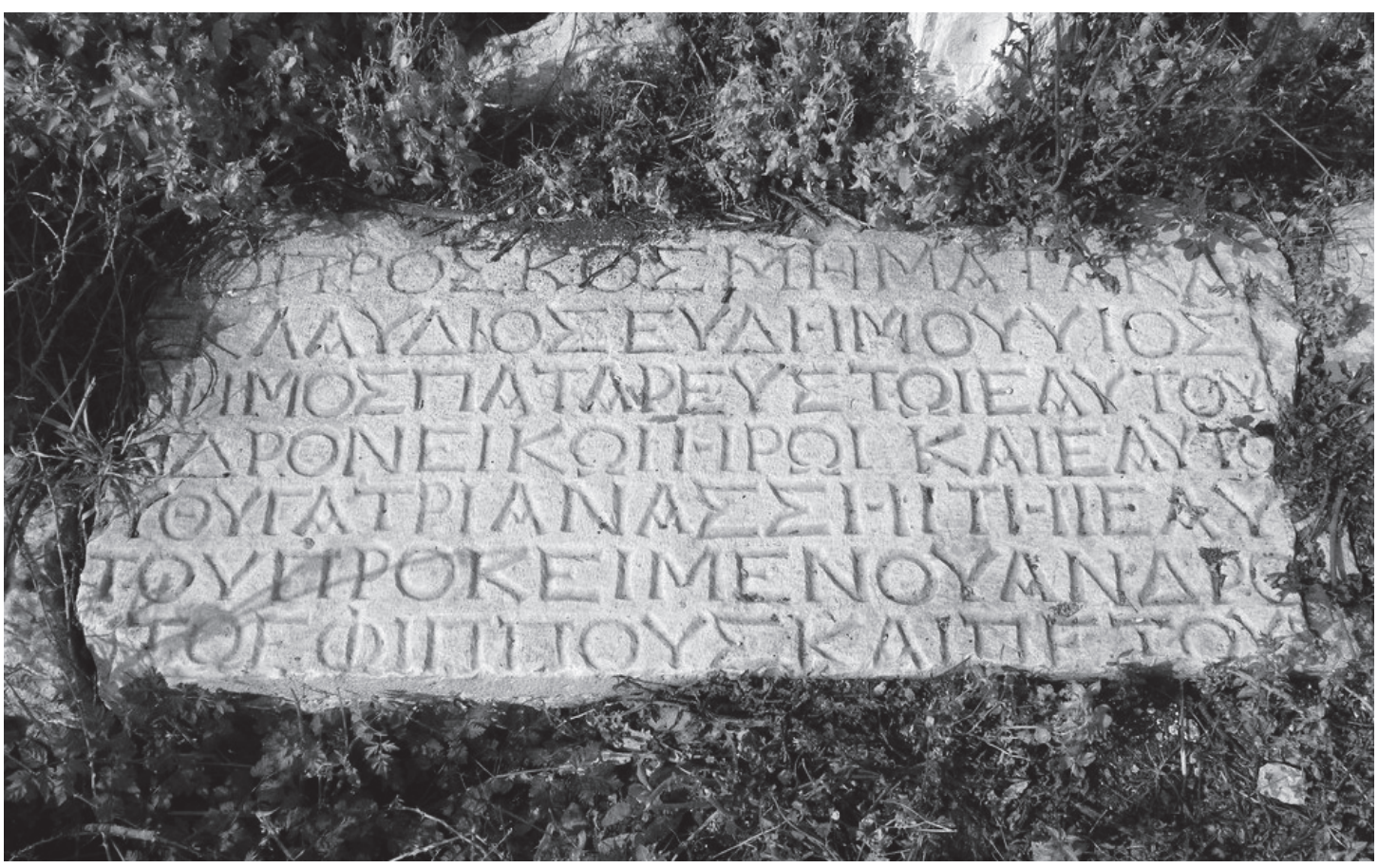

Fig. 4) Patara, Transept basilica, inscription reused as pavement slab (Adak 1996, n. 6). 


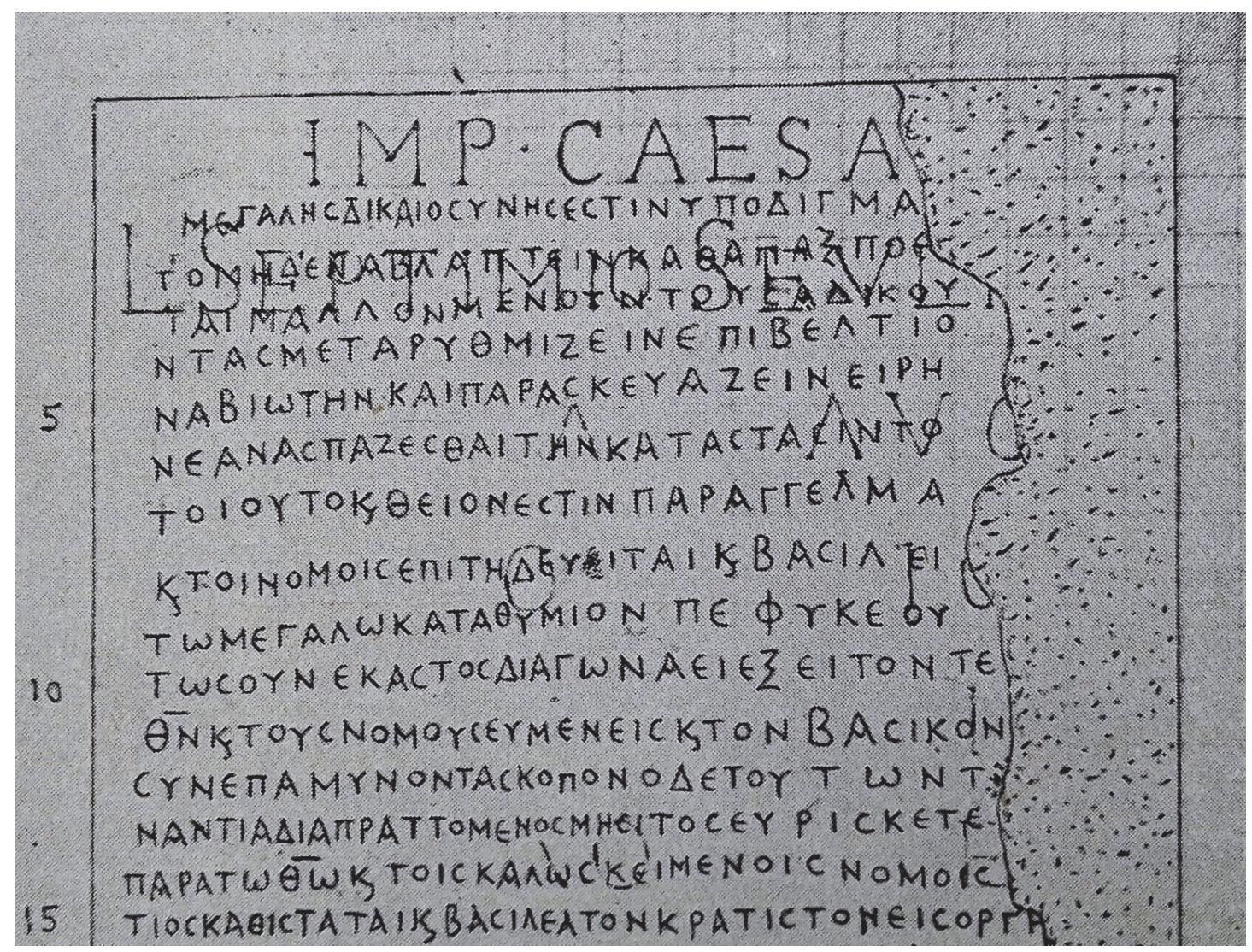

Fig. 5) Sardis, roman podium with an epigraphic palimpsest (Buckler-Robinson 1932, fig. 13).

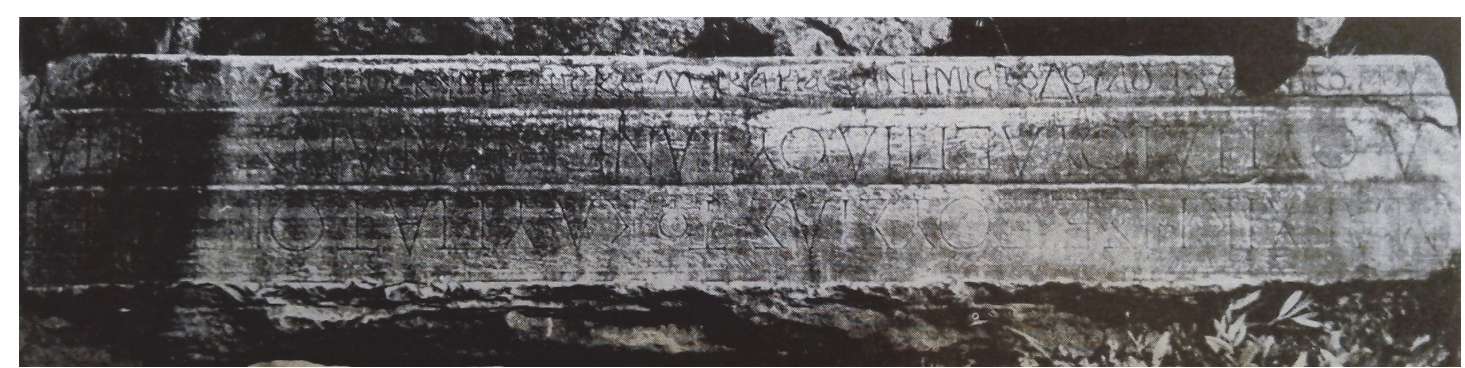

Fig. 6) Heracleia of Pontus, roman architrave reused as sarcophagus (Hoepfner 1966, Pl. 10e). 